\title{
Poetic Justice in Bill Cain's 9 Circles
}

\author{
Ghassan Awad Ibrahim
}

\author{
Department of English, Al-Turath University College, Baghdad, Iraq \\ Received: 14 Nov 2021; Received in revised form: 14 Dec 2021; Accepted: 20 Dec 2021 \\ (C2021 The Author(s). Published by TheShillonga. This is an open access article under the CC BY license \\ (https://creativecommons.org/licenses/by/4.0/)
}

\begin{abstract}
The research paper tackles difficult social problems such as raping and killing especially innocent people due to psychological diseases such as brutality and sadism which lead only to horrific consequences for both wrongdoers and victims. Poetic justice is a significant theme in all genres of literature since readers of any literary work expect that virtue is rewarded and vice is punished or in other words they expect good characters reap the fruit of what they previously sow of good deeds while bad characters deserve their disgraced destiny due to their malignant or bad deeds they have done before. In his masterpiece 9 Circles, Cain shows politics and its ways to impose its negative impact on the behavior of some people, prompting them to do evil attacks against others when he relies on a real story of an American soldier who tortures and kills not only some innocent people but also some animals for enjoyment.
\end{abstract}

Keywords-Poetic Justice, Horrific Consequences, Brutality, Politics, and Wars.

\section{INTRODUCTION}

The concept of poetic justice is a universal and significant theme not only worldwide but also in literature to achieve justice and social equilibrium. And if justice is not achieved somewhere in this world, literature would achieve it because "It was a widely held belief that literature should reflect a moral point of view and that a work of literature should reward the virtuous and punish the wicked." (Cuddon, 1980: p. 519) The term Poetic Justice is "invented by Thomas Rymer in Tragedies of the Last Age Considered (1678) to convey the idea that the evil are punished appropriately and the good rewarded as they should be." (Ibid, p. 519)

9 Circles which is written by the American playwright Bill Cain (born 1950) in 2010 concentrates on the brutal crimes of an American soldier against an Iraqi civilian family after the U.S. - led invasion to Iraq in 2003 to accomplish the concept of poetic justice.Evil has remained virtually unchanged since the creation of mankind. Agamemnon which is considered one of the ancient plays written in the fifth century B.C. by Aeschylus, a Greek playwright, shows that the protagonist, Agamemnon, and the military leader whose name bears the name of the play is so cruel that he slays his own daughter as a sacrifice to Apollo, a god in the Greek mythology, to stir the wind so that his military ships can move. After returning from the Trojan
War victorious, Agamemnon has been slain by his wife for committing the atrocious crime against their daughter "The general responsible for the victory at Troy, Agamemnon, is slain by his wife upon his return for the previous crime of having had his daughter slain as a sacrifice so the Greek ships might raise the winds to sail off to fight." (Malpede, 2011: xv) Moreover, children and women who are far away from war also cannot escape the brutality and atrocities of their enemies as the chorus in the play sings the following song which also criticizes war as it claims uncountable numbers of people lives "They came back, to widows, to fatherless children, to screams, to sobbing. The men came back, as little clay jars, full of sharp cinders, war is a pawnbroker - not of your treasures." (Aeschylus, 1999: p.24)

Thus, one of the most international social problems over ages is the cruel and violent treatment or behavior of man against other people which generates fears inside people, including playwrights, such as Cain to show in his masterpiece 9 Circles the atrocities and the civiliantrialto achieve justice of a real story of Steven Dale Green represented by Daniel Edward Reeves in the play, who served as an American soldier in the U.S. army during the U.S.-led invasion to Iraq in 2003. In fact, Reeves in Cain's play "was suggested by the true story of Steven Dale Green, a high school with a troubled emotional history who was in prison on his third misdemeanor charge just 
days before he was allowed to enlist in an army desperate for recruits." (Malpede, 2011: xxv)

Cain is so interested in literature, especially stories, that he expresses his own personal view about them since as he believes that stories are his "way of understanding the world. I think that's true for most of us. We can understand an event if we can fit it into a story - so we must be careful with our stories." (Cain, 2010: p. 4) Moreover, Cain believes that stories form man's personality when he expresses his own view about this important subject in the note of his play, writing:

I was five when I was first introduced to one of the stories that shapes our world on a daily basis. Since it was the first movie my parents ever took me to see, it made a tremendous, foundational impact on me. It was an allegory about a coalition of the Good who defeat absolute Evil with the help of God and brutal, murderous violence. It was called Walt Disney's Snow White and the Seven Dwarfs. It is the children's version of a story that shapes a great deal of our understanding of the world.

\section{(Cain, 2010: p.4.)}

Furthermore, it seems that Cain is also influenced by Sigmund Freud (1856-1939), the Austrian Neurologist and the founding father of psychoanalysis, who finds the solution of understanding his traumatized patients in reading and comprehending stories in English literature about violent acts, behaviour of characters and their past and how this literature paves the way to psychotherapy science it enables him to cure his mentally-disturbed people as Freudhimself confesses by his own words that "I have not always been a psychotherapist but was trained, like other neuropathologists, to use local diagnosis and electro-prognosis, and I myself still find it strange that the case histories that I write read like novellas and lack, so to speak, the serious stamp of science." (Freud and Breuer, 1952: p. 164) In her groundbreaking book, Trauma Explorations in Memory (1995), Cathy Caruth (born 1955), the American professor of English, confirms the significance of literature which lies in opening a window "on traumatic experience because it teaches readers to listen to what can be told only in indirect and surprising ways. Sociology, film, and political activism can also provide new ways of thinking about and responding to the experience of trauma." (Caruth, 1995: cover page) Moreover, Caruthjustifies and confirms that the literary influence on Freud was so thoughtful that he found literature indispensable in showing the inseparable relationship between literature and psychoanalysis when Caruth explains in her masterpiece Unclaimed Experience: Trauma, Narrative, and History (1996)that "If Freud turns to literature to describe traumatic experience, it is because literature, like psychoanalysis, is interested in the complex relation between knowing and not knowing. And it is, indeed at the specific point at which knowing and not knowing intersect that the language of literature and the psychoanalytic theory of traumatic experience precisely meet."(Caruth, 1996, p.3)

Compared to The Divine Comedy, written by the famous Italian poet Alighieri Dante (1265-1321), which according to Cain is "a vista full of blinding light where you can see what you have always hoped for - the love that moves the universe," (Cain, 2010: p. 5)9 Circles is a revelation of truth publicly as it is described by the playwright himself as saying that the play "is modeled, the soldier's journey in 9 Circles is a journey through terrible darkness into transforming light. In some of the darker scenes, it is important to remember this." (Ibid, p. 5)

\section{DISCUSSION AND ANALYSIS}

Although the short military service of Reeves in the U.S. Army while occupying Iraq, he has committed atrocities against an innocent Iraqi family. 9 Circles begins when Reeves is summoned by the officer in charge the "LIEUTENANT" to inform him that he is honourably discharged "Daniel Edward Reeves - an army private for less than a year - nineteen - maybe twenty - texas - enters. Lean. Intense.Standing at rigid military attention. This young man desperately wishes to remain a soldier. ... Honourable - discharge."(Cain, 2010: p. 9) In fact, Reeves has been too much annoyed as soon as he hears the order of his honourable discharge, asking the Lieutenant not to sign the order by telling him "Don't sign"as anindication of dissatisfactionwhen the latter intends to sign the order because he wants to remain a soldier. According to the following conversation, Reeves like some other of his young peers istrained to commit brutalities and atrocities, including killing people and this is the very thing which is confirmed by the Lieutenant when he wonders " Son, I don't know why they're sending your home. Seems to me you're everything we want in a soldier."(Ibid, p. 10)

REEVES. Some things don't bother me the way they bother other people. 


\section{LIEUTENAT. Like?}

REEVES.The basics, sir.Killing people. It bothers some people, sir.

LIEUTENAT. It doesn't bother you?

REEVES. Sir, we came here to kill people, sir.

LIEUTENAT.(Gung-ho.)

Soldier, we came here to help build a nation. That is our mission. Operation Iraqi Freedom. And that's a very unusual expression because it's both a euphemism AND oxymoron. You don't see a lot of them but when you do, run, because it means there are no words to describe the unspeakable fuck-up you are in.

REEVES.(Gung-ho-er.)hesitated

Sir, I don't mean we're here to kill all the people. Just the ones who hate freedom. Whoever is left when the killing stops - that's the nation.

LIEUTENANT. Son, I don't know why they're sending your home. Seems to me you're everything we want in a soldier. (checking his file.) You're nineteen?

(Ibid, pp. 10-11)

Moreover, the Army Attorney, another character in the play, confirms to Reeves that he is not only trained to do atrocities such as raping and killing peoplebut also prompting other soldiers to do the same evil things, advising him " not going to manipulate me like you manipulated those men - good men probably - in your squad. You got them to kill and to rape - and you did it easily - because that is what you were trained to do." (Ibid, p. 25)Therefore, one can discern that the authorities use Reeves or any other soldiers who are trained for special purposes of committing atrocities and brutalities for their own advantage as Chris Hedges in his forward in Karen Malpede'sActs of War: Iraq and Afghanistan in Seven Plays (2011) explains that "Those who make war work overtime to reduce love to smut, and all human beings become objects, pawns to use or kill."(Malpede, 2011: viii)Besides, in wars where any evil act is mostly justified, the American journalist Chris pours his tirade against warmongers, including politicians and religious institutions, considering them fraud that deceive people in a way that is illegal or dishonest:

War is always about betrayal. It is about betrayal of the young by the old, of cynics by idealists, and of soldiers and Marines by politicians. Society's institutions, including our religious institutions, which mold us into compliant citizens, are unmasked in war. This betrayal is so deep that many never find their way back to faith in the nation or in any god. They nurse a selfdestructive anger and resentment, understandable and justified, but also crippling. Ask a combat veteran struggling to piece his or her life together about God and watch the raw vitriol and pain pour out. They have seen the corruption and staggering hypocrisy essential to war. Those of us who refuse to heed their suffering and their words, brought to life in the hands of these playwrights, become complicit in the evil they denounce.

(Malpede, 2011: x)

For Reeves, he is so aggressive that he has the quality of anger and determination that make him ready to attack other people in cold blood. When he is in jail, wearing an orange jumpsuit as he has been already tried and convicted, he confesses to his heinous murders and is determined to do more: "GUILTY! GUILTY! I meant to say, 'Hand me over to Iraqis. Let them bury me up to my neck in sand and stone me to death. Televise it. I'll sing 'God bless America' till I'm dead and people will see what I'm made of and who those fucking people are."' (Cain, 2010: p. 23) Being sadist, Reeves is not only utterly obsessed in torturing and killing people but he is also infatuated with killing animals for fun. After being asked for several times by the civilian lawyer, another character in the play, who will be representing him in his current trial, about the reason that stands behind killing a dog, Reeves answered Fuck! the Dog!.

LAWYER. Why did you throw the dog off the roof?

Reeves. Fuck! The Dog!

LAWYER. You want to be guilty about something? Start here. You DID this. Why? Why did you throw the dog off the roof?

REEVES. I thought it was - (What?) - funny.

(Ibid, pp. 45-46)

Apparently, Reeves is a very dangerous man, and can be very brutal and reckless especially when he tells the LAWYER about what did he tell the shrink, a female 
psychiatrist who had met Reeves in the jail to discuss his wicked psyche that he "WANTED TO KILL EVERYBODY." (Ibid, p. 50)

In the early beginning of his trial, Reeves has denied all the accusations of his atrocitiesagainst him so that he may get away with murder, accusingrandomly insurgents of doing that "don't DO things LIKE THIS. Insurgents did this. We investigated it. That report - it's nothing but lies." (Ibid, p. 21) Earlier, Reeves after returning home(America) is arrested and taken to a police station for driving under the influence(DUI) of alcohol. In the police station he is informed by a Young Female Lawyer (YFL), a character in the play,according to a source of information that he brutally murders three Iraqi family members, including the father and little girl,in addition to the 14-year- old daughter whose bodyis set on fire after raping and killing her:

... Well - it says Private

Daniel Reeves and several of his squadmates - currently in the brig in Iraq - went to a house. There Private Reeves herded an Iraqi man, woman and child into the bedroom where he shot and killed them. Then he went into the living room where two of the soldiers were holding a woman down and he raped then killed her. Afterwards, they set her body on fire."

(Ibid, p. 21)

On March 2006, Reeves committed his capital crimes against the aggrieved family when he had shot the father, the mother, and their four-year-old daughter dead before raping and murdering their eldest daughter whose name is Hayat in the play meaning Life in English language while her real name is AbeerQasim Al-Janabi. Luckily, only two sons of the plagued family survived that horrific and disgraced event as they were at school. Ironically, the house where Reeves committed his atrocities is near a U.S. checkpoint in the town of the Al-Yusufiyah, which is situated near the large town of Mahmoudiya, some $35 \mathrm{~km}$ south of the Iraqi capital Baghdad. The large area where the towns of Al-Yusufiyah, Mahmoudiya, Iskandariyah, Latifiyah and Jurf Al Sakhar which lie between Baghdad and the province of Babel, some $100 \mathrm{~km}$ south of Baghdad is called The Triangle of Death because of the many attacks and explosionsoccurred there after the 2003 U.S.-led invasion to Iraq.

During the trial of Reeves, theprosecution, a group of lawyers who try to prove that a person in a trial is guilty, expressestheir sorrow over the terrible acts of Reeves, as saying: "It was not an 'event' or an 'incident'. It was a crime. Very real.Very brual."(Ibid, pp. 65-66)In her groundbreaking book, Trauma and Recovery: The Aftermath of Violence - From Domestic Abuse to Political Terror (2015), the American psychiatrist Judith Herman (born 1942), reveals that "The problem of coming to terms with endemic abuses of power also pertains to crimes of sexual and domestic violence. Because subordination of women and children has been so deeply embedded in our culture, the use of force against women and children has only recently been recognized as a violation of basic human rights." (Herman, 2015: p. 244)Besides, she reveals that the real nature of the American policy in falsifying facts "in the name of national security" so that the reality of America cannot be distorted openly by its some soldiers' atrocities committed in Iraq and Afghanistan:

Fighting in Iraq and Afghanistan, like the operations of CIA 'black sites' and NSA surveillance became all but invisible: outsourced, undeclared, off the books. A docile citizenry could go about its business, apparently unaware of or indifferent to the atrocities committed on its behalf, in the name of national security, by the U.S. military or by legions of clandestine 'contractors' who wore no uniforms. The active collusion of members of the legal profession enabled the pretense that war crimes were not war crimes. The active participation of members of the healing professions, particularly psychologists, in the sadistic rites of 'enhanced interrogation' enabled the pretense that torture was not torture.

(Ibid, p. 249)

Apparently, Reeves is not only a murderer of innocents but also a sadist who obtains pleasure from not only hurting other people and making them suffer physically or mentally as he confesses: "I make people nervous. People get careful - when they're around me." (Cain, 2010: p. 17) Furthermore, he has a debauched history as he practices sexual intercourse with his mother in the past and this the very thing which has been confirmed by the Army attorney when he discloses the crime of incest to Reeves, when 
mentioning his mother"You did what you could for her your mother. You tried to help out. My guess is that she relied on you as the man of the house.... That's a kind of incest, Mr. Reeves." (Ibid, p. 25)Malpede in her masterpiece Acts of War: Iraq and Afghanistan in Seven Plays (2011) is concerned over the heinous acts of some brutal and wicked people such as raping and murderingwhich are carried out by some U.S. soldiers in Iraq and Afghanistan, blaming religion for not enacting severe punishment against brutal acts and violence "If the New Testament prohibitions of sexual misconduct are to be stringently interpreted, why, then, are Jesus' injunctions against violence not binding in the same way? In other words, what does the commandment 'Thou shalt not kill' really mean?" (Malpede, 2011, viii) In fact, it is a crime when Reeves is enlisted as a private in the U.S. army since he is "deeply troubled nineteen-year-old with convictions for alcohol, drug abuse, violence." (Cain, 2010: p. 64) Reeves acts brutally when raping and killing Hayat after depriving her of her family because "Young girls," as the prosecution opines during the trial "need protection. The girl we are connected with living in a war zone - needed more than most. ... She had had another defense - her family. But a soldier deprived her of the protection of her family when he herded her father, her mother, and fouryear-old sister into the family bedroom and murdered them in cold blood." (Ibid, p.64)The Defense who is assigned to protect Reeves has tried to save his client from punishment as he told the court that Reeves is traumatized by war and that is why he is mentally disordered:

Daniel Reeves told anyone
who would listen he intended
to kill. He wanted to kill
everybody. More specifically,
all Iraqis.(Then) To his
everlasting credit, he sought
help. He went to an army
psychiatrist, asked for help,
was given unrecorded
medication, told to get a good
night's sleep and was recycled
the next day to patrol the area
known as The Triangle of
Death. With disastrous
consequences. What were his
superiors expecting?

(Ibid, p. 66)

Moreover, after reading a short story in the epic of the Italian poet Torquato Tasso (1544-1595), Freud concludes that the painful and traumatic events which are stored in the subconscious of the traumatized person can repeat themselves if they are triggered by a new horrific event. It is thus the epic is so significant to Freud in which:

Its hero, Tancred, unwittingly
kills his beloved Clorinda in a
dual while she is disguised in
the armour of an enemy knight.
After her burial he makes his
way into a strange magic forest
which strikes the Crusaders'
army with terror. He slashes
with his sword at a tall tree; but
blood streams from the cut and
the voice of Clorinda, whose
soul is imprisoned in the tree,
is heard complaining that he
has wounded his beloved once
again.

(Caruth, 1996, p.3)

In general, most of soldiers who fight in battlefields suffer from the trauma of seeing the horrific scenes of bloodshed in addition to the hard circumstances they live during wars. Therefore, many of them cannot control their behaviourfor a long time even after returning home as they suffer nightmares, deliria, hallucinations and anxiety. The American female professor Laurie Vickroy defines trauma "as a response to events so overwhelmingly intense that they impair normal emotional or cognitive responses and bring lasting psychological disruption." (Vickroy, 2002: ix) But during the trial of Reeves, the prosecution has proved that he is sane because he is able to think and behave normally and reasonably, and is not mentally ill when he cleverly explains that:

Mr. Reeves is a man, a smart
young man. He may have been
undereducated when he was
inducted into the army, but he
educated himself along the
way. He learned. (Then.) He
learned some Arabic.
Leadership skills.Even moral
virtue - loyalty - brotherhood
- self-sacrifice. He availed
himself of his opportunities
and, troubled by his desire to
kill, he - sought - help. And
the logical conclusion of this is
- unfortunately -(Then.) He
knew what he was planning on
doing - was wrong. (Then) He
knew it was wrong. (Then.)
And he did it anyway. This

Mr. Reeves is a man, a smart young man. He may have been undereducated when he was inducted into the army, but he educated himself along the way. He learned. (Then.) $\mathrm{He}$ learned some Arabic. Leadership skills.Even moral virtue - loyalty - brotherhood - self-sacrifice. He availed himself of his opportunities and, troubled by his desire to kill, he - sought - help. And the logical conclusion of this is - unfortunately -(Then.) $\mathrm{He}$ knew what he was planning on doing - was wrong. (Then) $\mathrm{He}$ And he did it anyway. This 
crime deserves - it demands

judgment.

(Cain, 2010: p. 67)

In his last words, Reeves is full of remorse, telling his story by his own words about his atrocities and brutalities of killing the innocent family and raping and killing its daughter: "This is my story. I did it. I raped her and I killed her family. I wish I didn't but I thought about it and I honestly don't see how anything could have been different." (Ibid, pp. 68-69)Furthermore, Reeves remembers the pathetic sight of the victimized girl when he has resisted all her entreaties to spare her life, remembering the dialogue between him and her who asks for help "Sa'idny. No act. I knew.I knew what she said. I'm smart. Sa'idny. I knew what she said. Help me. Help me. She said - Help. Me. (To her -) Show me. Show me how. (She speaks.) 'HaliniA'ish.' What? 'HaliniA'ish.' And I thought no. You don't want that. That's not what you want. Your family is gone. HaliniA'ishhhhhhh. Let me live." (Ibid, pp. 73-74) Moreover, he knows very well that Islamic religion instructs that any woman who commits adultery willingly must be stoned but in the case of Hayatshe is brutally raped in her own home and therefore she would be exculpated from her guilt according to the same religion. That is why he tells her a moment before he shoots her dead that "Even if they don't stone you, you'd always be alone. You don't know what that's like. You don't want that. You've never been. No, it's better this way. "Halini A - Bang."(Ibid, p. 74)

Cain has ended his dramatic text of 9 Circles by making his character Reeves faces death penalty(Blackout. A breathing out of a spirit into the darkness.)(Ibid, p. 75)But the reality is different. The fact is that Green does not face death penalty but a sentence of life in prison, therefore, poetic justice is fulfilled in the play."However, it seems that many people still think a work of literature should show some sense of justice: at its simplest, that the villain should get his deserts." (Cuddon, 1980: p. 519) Besides, Cain was asked in an interview carried out by the interviewer Sarah Saddler the following question:"You wrote the ending of 9 Circles before Green was sentenced to live in prison-can you explain why you chose to execute him?" He answered that "The absolute center of hell in Dante's Inferno is an extraordinary place. The center of hell is frozen, where even tears freeze in the eyes. Something about that spoke to me. In the very end of the play, he experiences an epiphany. As she was being raped, he was being raped. He was in the same position the girl was in. He was being raped."

https://etd.ohiolink.edu/apexprod/rws_etd/send file/send?a ccession $=$ miami $1371465573 \&$ disposition $=$ inline

\section{CONCLUSION}

In order to reform any society, there should be a reward and punishment to make sure that good behaviour is rewarded and bad one is punished so that the individuals of any society can live peacefully. In the case of Reeves who is brutal, reckless and snobbish, he wants to kill all people especially Iraqis because he is trained to do so according to the dramatic text of 9 Circles by his commanders to be so brutal, malicious and cruel as he intends not only to harm people but also to kill all of them. He deserves to face death penalty for committing crimes against humanity instead of sparing his life according to the court verdict which stipulates that he is sentenced to life imprisonment which gives a strong hint that his government is already lenient with criminals which may cause social disturbance in the future. By executing Reevesin the play (Green in reality) as a capital punishment which is legally and socially accepted to achieve social justice because Reeves deserves his disgraced and fatal destiny as he has committed severe crimes against innocent people. By writing the play, Cain, seemingly intends to say that law must be implemented to achieve justice in a worldwhich is mostly void of it.

\section{REFERENCES}

[1] Aeschylus (1999), The Oresteia, Ted Hughes (trans), Faber, London.

[2] Cain, Bill (2010), 9 Circles. New York, NY 10016. Dramatists Play Service, 440 Park Avenue South.All subsequent textual quotations and references which will appear in my thesis within parentheses in the text are based on this reference book. All spellings are kept as in the original.

[3] Caruth, Cathy (1995)Trauma Explorations in Memory.Baltimore and London.The Johns Hopkins University Press.

[4] Caruth, Cathy (1996) Unclaimed Experience: Trauma, Narrative, andHistory, Baltimore and London, JHU Press.

[5] Cuddon, J.A. (1980) A Dictionary of Literary Terms, United States of America, Doubleday \& Company, Inc.

[6] Freud, Sigmund and Breuer, Joseph (1952)Studies in Hysteria.London. Imago Publishing Co., Ltd.

[7] Herman, Judith (2015) Trauma and Recovery; The Aftermath of Violence - From Domestic Abuse to Political Terror. New York, Basic Books, A member of the Perseus Group.

[8] https://etd.ohiolink.edu/apexprod/rws_etd/send_file/send?acce ssion=miami1371465573\&disposition=inline.

[9] Malpede, Karen (2011) et. al. Acts of War, Iraq and Afghanistan in Seven Plays.United States of America.Northwestern University Press.

[10] Vickroy, Laurie (2002).Trauma and Survival in Contemporary Fiction.Charlottesville and London, University of Virginia Press. 